\title{
ASSESSING THE RUSSIAN MAJOR BANKS' CONTRIBUTION TO THE SYSTEMIC LIQUIDITY RISK PROPAGATION IN BANKING
}

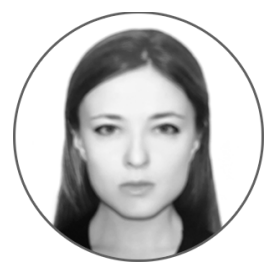

Article history:

Received 12 January 2018

Received in revised form

22 February 2018

Accepted 1 March 2018

Translated 18 December 2018

Available online 24 December 2018

JEL classification: E69, F30, G17, G21, G32

Keywords: systemic risk, macroprudential regulation, banking, systemically important bank, systemic significance

\author{
Ekaterina V. SERYAKOVA \\ Moscow State Institute of International Relations (University) \\ of Ministry of Foreign Affairs of Russian Federation, Moscow, Russian Federation \\ ekaterinaseryakova@yandex.ru
}

\begin{abstract}
Subject The 2007-2009 global financial crisis proved that the banking sector cannot evolve without concerted actions of the regulator. Systemically important institutions inter alia generate the systemic risk. The article discusses concepts, phases and tools of macroprudential regulation, evaluates how Russia's Top 10 banks influence the systemic liquidity risk.

Objectives The research develops the aggregate index of major banks' contribution to the systemic liquidity risk. Methods The research involves the methods of econometric and logical analysis.

Results I built up the weighted aggregate index of Top 10 Russian banks' contribution to the systemic liquidity risk in the domestic banking sector. The article measures the statistical significance of systemic importance factors per each bank. Three group of banks are pointed out, which have certain systemic importance metrics of statistical significance.

Conclusions and Relevance The proposed index is forward looking by nature as compared with Russia's Industrial Production Index and nominal GDP. An increase in major banks' contribution to the systemic liquidity risk hinders an economic growth and IPI trends.
\end{abstract}

The editor-in-charge of this article was Irina M. Vechkanova Authorized translation by Irina M. Vechkanova

The 2007-2009 global financial crisis revealed that the banking sector cannot thrive and go forward without concerted efforts of the regulatory authorities. Globally, financial stability issues are coordinated by the Financial Stability Board, which was established by the G20 nations at the 2009 London Summit and called to outline regulatory policy for maintaining the financial stability.

${ }^{\dagger}$ For the source article, please refer to: Серякова Е.В. Оценка влияния крупнейших российских банков на распространение системного риска ликвидности банковского сектора. Финансовая аналитика: проблемы и решения. 2018. Т. 11. № 3. С. 326-341. URL: https://doi.org/10.24891/fa.11.3.326
In 2010, the European Union set up the European Systemic Risk Board to conduct the ongoing monitoring of financial risks and evaluate the economic situation of the EU countries.

Hence, the international community admitted that national and supra-national regulators should prioritize the macrofinancial stability through a macroprudential policy.

The term macroprudential policy originated in the 1970s. This phenomenon used to be regarded from perspectives of possible measures to mitigate the adverse effect of the banking system on the macroeconomy [1]. 
Macroprudential policies envisage a set of actions the Central Bank of Russia undertakes as the regulator to mitigate systemic risks ${ }^{1}$.

According to documents of the Bank for International Settlements, there is a reasonable need to shift from the macroprudential regulation to macroprudential oversight and regulation. Experts believe that the macroprudential policy will limit systemic risks, being countercyclical by nature. That is, it should prevent that the banking market actors would underestimate systemic risks during the period of economic expansion and, correspondingly, overestimate them during the economic recession. Furthermore, macroprudential regulation helps control possible governmental spending on the recovery of certain banks' financial stability after crisis phenomena [2].

Macroprudential regulation tools can be classified through characteristics of the systemic risk.

Timing effects show up when the systemic risk grows over time. Macroprudential policies provide for such effects to eliminate the procyclicity in the banking system.

Spatial effects arise when the systemic risk spreads across the entire banking system. Such effects are taken into consideration to reduce the systemic risk concentration.

The systemic risk may be triggered by macroeconomic, market conditions and systemically important financial institutions [2].

As I mentioned above, such banks generate the systemic risk. Thus, it is important to identify systemic significance tests and measure the contribution of such institutions to the total systemic risk of the banking system.

As per the Basel III Accord and standards of the European Banking Authority (EBA), there are five tests and corresponding indicators (Table 1) ${ }^{2}$.

First of all, macroprudential regulation should focus on its sources, i.e. systemically important banks. To timely apply tools of respective policies, it is necessary to

\footnotetext{
${ }^{1}$ Macroprudential Policy. BIS Papers, 2016, September, no. 86. URL: https://www.bis.org/publ/bppdf/bispap86.pdf

${ }^{2}$ Basel Committee on Banking Supervision: A Framework for Dealing with Domestic Systemically Important Banks. 2012, October, 17 p. URL: https://www.bis.org/publ/bcbs233.pdf
}

address all systemic risk mitigation aspects step by step.

The systemic significance of each bank should be assessed with respect to different periods to analyze their impact on the total systemic risk. However, Top-10 banks (amount of assets) and their systemic significance should also be taken into account but involving other systemic significance indicators.

Macroprudential regulation requires to use groups of tools influencing the capital, assets and liquidity.

It is worth mentioning that each tool should be applied for some purpose of macroprudential regulation to reduce endogenous risks that may grow into systemic ones due to the procyclicality of banking market actors, their close and mutual relationships based on reciprocal obligations and concerted activities (Table 2).

I provide a more detailed description of financial tools helping to achieve specific goals.

The systemic risk buffer constitutes an additional capital expressed in a percentage of the risk weighted assets. This instrument increases the long-term resilience of separate segments and financial sector as a whole, helps prevent structural shocks that are not caused by cycles (for example, amendments to accounting rules or standards, etc.).

The capital buffer enhances financial strengths in this case, thus allowing the system survive potential losses.

Although the instrument is mainly intended as a shield from the structural systemic risk, it can also be used for risks associated with business cycles. The instrument may be adopted for one, several or all institutions.

Macroprudential restrictions on an industry or class of assets represent the statutory restrictions on the bank's activities in a certain sector or class of assets, which are measured as a percentage of capital stock.

H6 standards of the Central Bank of Russia (H25 standards for a banking group) make one of the best examples since they set forth the maximum risk per borrower or group of related borrowers (the debt to capital ratio).

The buffer becomes an additional capital for systemically important banks. It is measured like other capital buffers as a percentage of risk weighted assets.

The instrument makes the systemic risk less probable, which may originate from a systemically important bank 
curbing its operational risks. The buffer may differ in each institution. The specific amount is determined per each bank in proportion to its contribution to the systemic risk.

The counter-cyclical capital buffer is compulsory to increase the amount of capital measured as a percentage of risk weighted assets and can be altered during the financial cycle.

The instrument is intended to hinder the credit expansion and credit bubble, limiting the bank leverage.

On the one hand, as seen in its naming, the countercyclical capital buffer reduces the procyclical activities of a bank institution. On the other hand, as the capital buffer increases, banks will continue to grant loans even during crises, thus cushioning a drop in GDP.

The sectoral (anti-cyclical) capital buffer is a temporary capital buffer required since banks influence specific sectors or classes of assets to alleviate the lending concentration in sectors exposed to a growing systemic risk.

The sectoral capital buffer is expressed as a percentage of risk weighted assets. It can be adjusted during the financial cycle and set by two methods:

1) introducing the weight of sectoral risk (for example, a higher weight is assigned to housing, construction and unsecured retail loans);

2) introducing an additional capital buffer in line with risk weighted activities of banks in certain sectors.

Macroprudential restriction on the debt to equity ratio of a bank indicates the minimum threshold of the bank's equity to assets ratio. It prevents banks from incrementing their assets in an uncontrollable manner. The indicator is added to those tools intended to ensure the capital adequacy.

Loan-to-value ratio is the limitation of the maximum loan amount against the value of an assets pledged. The LTV limit directly requires the minimum collateral and predetermines the amount of loan, thus reducing the would-be borrowers' default risk. At the macrolevel, LTV ratio mitigates the systemic credit risk.

Loan-to-income (LTI) ratio limits the biggest amount that can be borrowed against the borrower's income.

LTI ratio is similar to LTV ratio in curbing excessive borrowings. In the mean time, the instrument also serves for making lending decisions with regards to risky groups of customers. LTI can be more effective than LTV when real estate prices grow since real estate is often used as mortgage.

To prevent a too large gap between assets and liabilities by term and likelihood of the systemic structural liquidity risk, liquidity coverage ratio (LCR) and net stable funding ratio (NSFR) are used.

If the institution depends on short-term sources of finance, it may suddenly run out of liquid assets and have to organize a fire sale of its assets. Such situations trigger financial risks as they are mutually related (systemic structural risk). LCR is a statutory requirement of the regulator, being the ratio of highly marketable assets to liabilities with maturity up to 30 consecutive days.

Unlike LCR governing the short-term liquidity level, the net stable funding ratio (NSFR) relates to a requirement to cover a certain amount of non-current assets with available long-term funds within a year.

Loan-to-deposit ratio (LTD) is the maximum ratio of loans to bank's deposits. It is applied to ease the excessive dependence on less stable sources of finance, make more stable sources of finance more attractive, for example, deposit. It can be altered during the financial cycle.

Macroprudential policy can have a dual effect on the development of a financial system like any restrictions imposed on any system.

All macroprudential regulatory tools are variable and permanent.

Variable tools imply that values of prudential restrictions are revised in line with an economic cycle and applied on a differential basis or modified automatically (systemically important institutions buffer).

Variable tools mostly regulate the procyclicality of banks' activities, influencing their balance (LCR, NSFR, dynamic rates of reserves, counter-cyclical and sectoral capital buffers) or lending terms.

Permanent tools include leverage and capital requirements.

Unlike microprudential regulation, macroprudential regulation draws upon the systems approach allowing to identify peaks of the banking sector with respect to the real economy even if some agents of the banking 
system are compliant with microprudential requirements.

It is noteworthy that the macroprudential approach treats the risk as an endogenous factor arising from simultaneous activities of banks or exposure to the same shocks [3].

Table 3 summarizes the principal difference of the regulatory methods.

Goals, purposes and principles of macroprudential policy were articulated after the 2008-2009 global financial crisis when researchers found what caused the financial instability and propagation of systemic risks. Initially, the general purpose of macroprudential policy was to sustain the financial stability. However, this statement needs to be clarified.

There are two main approaches to interpreting the financial stability. As per the first one, financial stability means the effective functioning of the national financial system, though being influenced by external shocks. As per the second one, financial stability results from the resilience of the financial system to internal shocks [4].

The two approaches can be integrated to denote compulsory traits of macroprudential policy:

- it shall be counter-cyclical;

- macroregulation mainly aims to identify, monitor and limit systemic risks and curb social effects of systemic crises affecting the financial system;

- macroprudential regulation shall focus on systemically important financial institutions (too-bigto-fail) as origins of systemic risks;

- such regulation shall ensure the smooth operation of the financial system throughout business cycle phases;

- macroprudential regulation should pursue to reduce possible governmental expenditures to recover the financial resilience of certain institutions or financial system after the systemic crisis [2].

Macroprudential policy also serves for preventing the financial instability. In my opinion, this definition is more comprehensive and concrete than the interpretation based on the financial stability term [5].

The financial system is believed to be stable if it is able to allocate resources effectively and absorb shocks, impede their destructive impact on the real economy and other financial systems [6].

I point out some definitions of financial instability that is the leading idea of macroprudential policy. Financial instability is understood as a situation when the economy may be affected by fluctuating prices for financial assets or instability of financial institutions to fulfill their contractual obligations [7].

Financial instability is also construed as a situation described with three key criteria:

1) prices for some key financial assets strongly deviate from their fundamental principles;

2) credit market operations are disturbed;

3) aggregate expenditures significantly deviate from their benchmark level [8].

So, macroprudential regulation of the banking sector pursues two key goals as follows:

- neutralizing the procyclicality of the banking system and its impact on financial and business cycles (timing effect of the systemic risk);

- reinforcing the sustainability of the financial system, strengthening the ability to overcome economic crises, without causing unfavorable consequences for functions of the system (structural effect of the systemic risk) [9].

Goals determine a set of tasks macroprudential regulation is to address. In 2016, the Financial Stability Board, International Monetary Fund and Bank for International Settlements released a macroprudential policy report ${ }^{3}$.

The report sorts the tasks into three groups:

- smoothing the financial cycle;

- strengthening the resilience of the financial system to shocks by making capital and liquidity buffers during periods of economic growth;

- monitoring major financial institutions' risks and identifying pipelines of such risks.

Macroprudential policy tasks can be detailed as follows:

- reinforcing the sustainability of financial infrastructure;

\footnotetext{
${ }^{3}$ IMF-FSB-BIS Elements of Effective Macroprudential Policies. Lessons from International Experience, 2016.

URL: http://www.imf.org/external/np/g20/pdf/2016/083116.pdf
}

Please cite this article as: Seryakova E.V. Assessing the Russian Major Banks' Contribution to the Systemic Liquidity Risk Propagation 
- preventing the concentration of financial institutions' risks in certain sectors or classes of assets;

- curbing the systemic effect of incentives to support certain financial institutions and reduce the risks of loss of confidence in the financial system;

- stifling an excessive growth in lending and financial leverage in banking;

- preventing the term of assets and liabilities from becoming too unbalanced.

Fig. 1 highlights key phases of macroprudential policy [2].

The effective macroprudential regulation is indispensable without an elaborate mechanism for identifying, assessing and monitoring the systemic risk, i.e. the early warning system which senses the likelihood of financial disparities.

Such a mechanism can be build by banks individually to recover their financial sustainability when their operations exceed thresholds of market environment metrics (exchange rate of the Russian ruble against the dual currency basket, stock indices, volatility of stock indices, spreads between the monetary market rates and key interest rate), macroeconomic indicators (oil prices, GDP growth rates, inflation, etc.) and rates or restrictions (rates of the Central Bank of Russia, survival horizon limit in case of stress tests of liquidity risk, sectoral concentration of the loan portfolio, etc.).

Once the systemic risk is found to be probable or increase, it is necessary to decide which macroprudential instruments should be activated and strengthened/softened/canceled and indicate the time to do so.

Systemic risks are detected and respective tools are chosen through monitoring and analysis of risk metrics and their trends. Selecting the appropriate tools, it is important to know what caused the systemic risk, i.e. too-big-to-fail financial institutions, endogenous cumulative disparities in the banking system or exogenous market factors and macroeconomic shocks.

Macroeconomic instability often activates several tools, which streamlines the attainment of various interim goals. However, it should be remembered that macroprudential policy measures have a reciprocal effect. Each goal requires an individual approach and set of tools.
There are two pending issues of macroprudential regulation to be resolved. There should be a common list of macroprudential regulation measures and methods to evaluate their efficiency.

Nowadays macroprudential regulation is evaluated and coordinated at the international level. First of all, clarity is needed to understand which tools should be used throughout phases of the financial cycle. Researches, which mainly evaluate the impact on banks' balance sheet figures, focus on asset regulation tools only.

The institutional design of macroprudential policy is another matter to discuss. International practices persuade that it is the central bank that should be responsible for macroprudential regulation since it is an integrated regulatory authority in the financial market, thus proving to be the most constructive option. Experts point out drawbacks and advantages of such regulation (Table 4).

Currently, Russia's banking sector stagnates. According to S\&P Global Ratings, the banking sector should expect the following challenges to come in 2018:

- escalating competition among banks against low economic growth rates and dropping interest margin;

- expanding market presence of State-owned banks ${ }^{4}$;

- increasing concentration risks, especially loan portfolio [10].

As for positive trends, non-performing loans will freeze at a 10 percent level, while retail lending is expected to grow.

In 2017, the Central Bank of Russia underlines the following material risks:

- reserves risks;

- concentration risks since the concentration of major borrowers is predicted to increase;

- fair value risk associated with securities.

Bank authorities should toughen their regulatory activities and find new methods to support failing banks in order to address and resolve the existing challenges of the financial sector.

In the summer of 2017, the Central Bank of Russia had to assume the financial recovery campaign for Otkritie

\footnotetext{
${ }^{4}$ At the end of 2017 , State-owned banks are predicted to account for 62 percent of the market.
} 
Bank (systemically important bank) and BINBANK. Therefore, anticipating probable challenges and avoid the bailout of large banks, the macroprudential policy mechanism shall be refined.

As mentioned above, the community lacks a clear understanding which tools would be appropriate for financial cycle phases. In Russia, the integrated regulatory authority maps risks and assigns indices to each of them [11-14].

As put in the financial stability overviews for 2016, the Central Bank of Russia recognizes the following types of risks:

- sovereign risk;

- bank risk;

- market risk (currency and equity risks);

- liquidity risk;

- real economy risk;

- foreign trade risk.

I suggest using the aggregate index of major banks' contribution to the systemic liquidity risk, which is weighted by the systemic importance degree of a bank. If banks are evaluated this way, this will allow to pinpoint the source of the systemic risk and group major banks having the same systemic significance characteristics, thus applying macroprudential policy tools on an ad-hoc basis.

Thresholds of the aggregate index of major bank's (Top 10) contribution to the systemic liquidity risk propagation may indicate when liquidity tools of macroprudential regulation shall be integrated $^{5}$ [15-17].

Based on the data array from January 1, 2012 through August 1, 2017, I set a regression for each bank and assessed their determination coefficients reflecting the systemic importance of each bank. They are taken as each bank's weight to compute the aggregate index as of each date. The variable of each bank's

\footnotetext{
${ }^{5}$ Guidance to Assess the Systemic Importance of Financial Institutions, Markets and Instruments: Initial Considerations. Briefing Paper for the G20 Finance Ministers and Central Bank Governors, 2009. URL: http://www.imf.org/external/np/g20/pdf/100109a.pdf

Financial Stability Risks, Monetary Policy and the Need for MacroPrudential Policy (Speech by V. Constancio, Vice-President of the ECB, Warwick Economic Summit, 13.02.2015). URL:

http://www.ecb.europa.eu/press/key/date/2015/html/sp150213.en.html What Is Systemic Risk? URL: http://www.systemic-risk-hub.org
}

contribution to the variance of net liquidity position of the bank system was taken as a dependent variable:

$$
R C=\operatorname{cov}(n l p, N L P) / \sqrt{\operatorname{VaR}(N L P)},
$$

where $n l p$ is surplus (shortage of) liquidity of each bank;

$N L P$ is surplus (shortage of) liquidity in the banking system.

nlp, as of each date, is computed as the balance of the bank's liquid assets and current liabilities (up to 30 days). NLP, as of each date, is measured as difference between the banking system's amount due to the Central Bank of Russia and amounts expected from it.

Systemic significance factors are accepted as regressors (Table 5) ${ }^{6}[18]$.

The research provides the following results.

1. I built up the weighted aggregate index of Russia's Top-10 banks' contribution ${ }^{7}$ to the systemic liquidity risk of the Russian banking sector (Fig. 2).

2. Statistical significance of regressors (systemic significance factor) was measured to apply macroprudential policy tools to each of Top-10 banks on an ad-hoc basis.

The research demonstrated that

- Bank's liabilities, approximating metric Size are not statistically significant for Top 3 banks of Russia. Therefore, international experts' hypothesis is verified stating that the size of a bank is a necessary but still insufficient metric to understand the bank's contribution to the systemic liquidity risk ${ }^{8}$;

- dependence on the interbank lending market is statistically significant with respect to Top 5 banks (in terms of assets and capital) to measure banks' contribution to the systemic liquidity risk (Sberbank, Russian Agricultural Bank, Otkritie Bank);

- the share of individuals' deposits that gives an approximation for the substitution among the banking sector's deposits is a statisically significant criterion for four banks (VTB24, Alfa Bank, Promsvyazbank, Otkritie Bank).

\footnotetext{
${ }^{6}$ Global Financial Stability Report: Grappling with Crisis Legacies, 2011

${ }^{7}$ Top 10 banks were selected in terms of assets and capital, as of August 1, 2017. Please refer to the website URL: www.kuap.ru (In Russ.)

${ }^{8}$ Significance of regressors is hereinafter assessed within a 99-percent confidence interval.
} 
1. Three groups of banks were found, for which some systemic importance metrics are statistically significant (Table 6).

2. I analyzed hypothesis on the sign of regressor coefficients with model values (Table 7).

3. The index is showed to be a leading indicator with respect to nominal GDP and quarterly growth rate of Industrial Production Indicator (Fig. 3).
4. Using the Granger causality test, I detected the causeand-effect relationship between the index and quarterly growth rate of Industrial Production Index. These are changes in the first index that are followed by unidirectional changes in the second one.

The proposed index can be used by the Central Bank of Russia's department in charge of financial stability.

\section{Table 1}

Criteria and key metrics of systemic importance of banks

\begin{tabular}{ll}
\hline Criterion & Metric \\
\hline Size & $\begin{array}{l}\text { Amount of assets. Amount of liabilities. Risk weighted assets / GDP. Liabilities / capital. Liabilities / GDP. Bank's } \\
\text { market share. Bank's market capitalization / general capitalization of banks. Value of off-balance sheet receivables } \\
\text { and liabilities }\end{array}$ \\
\hline Interdependency & Interbank loans granted. Interbank loans taken. Securities in circulation \\
\hline Substitution & Retail deposits. Retail loans. Stocks and bonds pledged to secure REPO transactions \\
\hline Complexity: & Number of branches. Number of subsidiaries. Number of foreign companies \\
- institutional & Receivables and liabilities denominated in foreign currency \\
- international & Amount of OTC derivatives. Percentage of interbank loans taken out from non-residents within total interbank loans. \\
- operational & Valued of asset-backed debt
\end{tabular}

Source:Authoring

Please cite this article as: Seryakova E.V. Assessing the Russian Major Banks' Contribution to the Systemic Liquidity Risk Propagation in Banking. Digest Finance, 2018, vol. 23, iss. 4, pp. 441-452. https://doi.org/10.24891/df.23.4.441 


\section{Table 2}

Macroprudential policy tools and their metrics in terms of its objectives

\begin{tabular}{|c|c|c|c|}
\hline Tool & Metric & Objectives & Respective risk \\
\hline \multicolumn{4}{|l|}{ Tools for capital } \\
\hline Counter-cyclical capital buffer & Counter-cyclical capital buffer & $\begin{array}{l}\text { Smoothing the procyclical activity } \\
\text { of the bank in the short run. } \\
\text { Curbing and preventing an excessive } \\
\text { growth of lending and leverage }\end{array}$ & \multirow[t]{2}{*}{$\begin{array}{l}\text { Credit risk: a decreased growth } \\
\text { of a loan portfolio through } \\
\text { more valuable funding }\end{array}$} \\
\hline Sectoral capital requirements & $\begin{array}{l}\text { Volume and price of loans per tool. } \\
\text { Restrictions on the sectoral } \\
\text { concentration of borrowers. } \\
\text { Restriction on the price for loan backing. } \\
\text { Position limits on securities }\end{array}$ & $\begin{array}{l}\text { Curbing and preventing an excessive } \\
\text { growth in lending and leverage. } \\
\text { Smoothing and preventing } \\
\text { the concentration of financial } \\
\text { institutions' risks in certain sectors } \\
\text { or classes of assets }\end{array}$ & \\
\hline $\begin{array}{l}\text { Tier I capital buffer for systemically } \\
\text { important banks }\end{array}$ & $\begin{array}{l}\text { Tier I capital buffer for systemically } \\
\text { important banks }\end{array}$ & $\begin{array}{l}\text { Increasing the adequacy of } \\
\text { systemically important banks' capital } \\
\text { to cover unexpected losses }\end{array}$ & $\begin{array}{l}\text { Disparity risks of systemically } \\
\text { important banks }\end{array}$ \\
\hline \multicolumn{4}{|l|}{ Tools for liquidity } \\
\hline \multirow{3}{*}{$\begin{array}{l}\text { Counter-cyclical liquidity } \\
\text { requirements }\end{array}$} & LCR (liquidity coverage ratio) & Current liquidity regulation & \multirow[t]{4}{*}{ Funding liquidity risk } \\
\hline & NSFR (net stable funding ratio) & $\begin{array}{l}\text { Regulating non-current liquidity } \\
\text { and share of unstable funding }\end{array}$ & \\
\hline & LTD (loan to deposit ratio) & Loans (deposit) & \\
\hline Market premiums and rebates & $\begin{array}{l}\text { Discount ceiling to secure loans. } \\
\text { Liquidity premium. Financial market } \\
\text { depth }\end{array}$ & - & \\
\hline \multicolumn{4}{|l|}{ Tools for assets } \\
\hline LTV / LTI & $\begin{array}{l}\text { The loan-to-value ratio. } \\
\text { The loan-to-income ratio }\end{array}$ & $\begin{array}{l}\text { Decrease in loss given default } \\
\text { of banks. } \\
\text { Decrease in the probability } \\
\text { of borrower's default }\end{array}$ & \multirow[t]{2}{*}{ Credit risk } \\
\hline Dynamic reserves & $\begin{array}{l}\text { Making additional reserves during the } \\
\text { period of economic expansion to utilize } \\
\text { them during the economic recession }\end{array}$ & $\begin{array}{l}\text { Smoothing a decrease in the bank's } \\
\text { margin during crises }\end{array}$ & \\
\hline
\end{tabular}

Source:Authoring

\section{Table 3}

Differences between microprudential and macroprudential regulations

\begin{tabular}{|c|c|c|}
\hline Indicator & Microprudential regulation & Macroprudential regulation \\
\hline Goals & $\begin{array}{l}\text { Protection of depositors and creditors' interests. } \\
\text { Ensuring the financial sustainability of certain banks }\end{array}$ & $\begin{array}{l}\text { Mitigation of the systemic risk, effect of the procyclical } \\
\text { nature of risk assessment }\end{array}$ \\
\hline \multirow[t]{2}{*}{$\begin{array}{l}\text { Role of macroeconomic indicators } \\
\text { and risk assessment approaches }\end{array}$} & $\begin{array}{l}\text { Material risks for specific banking groups and inherent } \\
\text { risks }\end{array}$ & Assessment and mitigation of systemic risks \\
\hline & $\begin{array}{l}\text { The risk assessment method involves the analysis } \\
\text { of standard forms of bank reporting }\end{array}$ & $\begin{array}{l}\text { The risk assessment method is based on the scenario } \\
\text { analysis and stress testing of the banking system } \\
\text { (top-down) }\end{array}$ \\
\hline $\begin{array}{l}\text { Prudential standards implementation } \\
\text { technique }\end{array}$ & Bottom-up & Top-down \\
\hline Disclosure & Confidential standard reports & $\begin{array}{l}\text { Wide use of assessments, including macroprudential } \\
\text { early warning indicators }\end{array}$ \\
\hline
\end{tabular}

Source:Authoring 


\section{Table 4}

Strengths and weaknesses of macroprudential regulation by central banks

\begin{tabular}{ll}
\hline Strengths & Weaknesses \\
\hline $\begin{array}{l}\text { Effective exchange of results with respect to the monetary } \\
\text { and macroprudential policy }\end{array}$ & Conflicting goals of monetary and macroprudential policies \\
\hline $\begin{array}{ll}\text { Central bank's intention as a creditor of last resort to maintain } \\
\text { the financial stability of the entire banking system }\end{array}$ & $\begin{array}{l}\text { Versatile and understandable tools of monetary policy unlike measures } \\
\text { of macroprudential policy. Consequently, the public confidence risk arises } \\
\text { with respect to the independence of the integrated authority's policy }\end{array}$ \\
\hline
\end{tabular}

Source:Authoring

\section{Table 5}

Criteria and metrics of banks' systemic importance used as regressors

\begin{tabular}{ll}
\hline Criterion & Metric \\
\hline Size & Bank's liabilities \\
\hline Interdependency (with banking system) & Balance of interbank loans (granted and obtained) and comprehensive liabilities \\
\hline Substitution & $\begin{array}{l}\text { Stocks and bonds as part of REPO transactions. The ratio of individuals' term } \\
\text { deposits in total deposits of the banking sector }\end{array}$ \\
\hline Complexity: & Share of amounts due to foreign banks in total interbank loans obtained. \\
- operating activity & Balance of bank's receivables and liabilities denominated in foreign currency \\
\hline
\end{tabular}

Source:Authoring

Table 6

Grouping of banks by statistically significant indicator

\begin{tabular}{ll}
\hline Statistically significant indicators & Banks \\
\hline Size and substitution, substitution_deposits & VTB24,_Alfa Bank, Promsvyazbank, National \\
& Clearing Center \\
\hline Relationship (interbank) and complexity of operations (complexity_operational) & Sberbank, Russian Agricultural Bank, Otkritie \\
& Bank \\
\hline International operations (complexity_international) & VTB, Gazprombank, Moscow Credit Bank \\
\hline
\end{tabular}

"The indicator proved to be statistically significant within a 90-percent confidence interval.

Source:Authoring

Table 7

The impact of the regressors on the bank's contribution to systemic liquidity risk

\begin{tabular}{llll}
\hline Criterion & Hypothesis & Banks & Regression coefficient sign \\
\hline Substitution (deposits) & The fact that the bank is important & VTB24. & + \\
& $\begin{array}{l}\text { in accumulating deposits has the positive effect } \\
\text { on its contribution to the systemic liquidity risk }\end{array}$ & Alfa Bank & + \\
\hline Relationship & The fact that the bank depends on interbank loans & Sberbank. & - \\
& increases its contribution to the systemic liquidity & Russian Agricultural Bank. & + \\
& risk & Otkritie Bank & + \\
\hline Size & The greater the bank's assets (liabilities), & VTB24. & - \\
& the greater its contribution to the systemic & Alfa Bank. & - \\
& liquidity risk & National Clearing Center. & + \\
& & Russian Agricultural Bank. & - \\
& Otkritie Bank & + \\
\hline
\end{tabular}

Source:Authoring

Please cite this article as: Seryakova E.V. Assessing the Russian Major Banks' Contribution to the Systemic Liquidity Risk Propagation in Banking. Digest Finance, 2018, vol. 23, iss. 4, pp. 441-452. 
Figure 1

Macroprudential policy phases

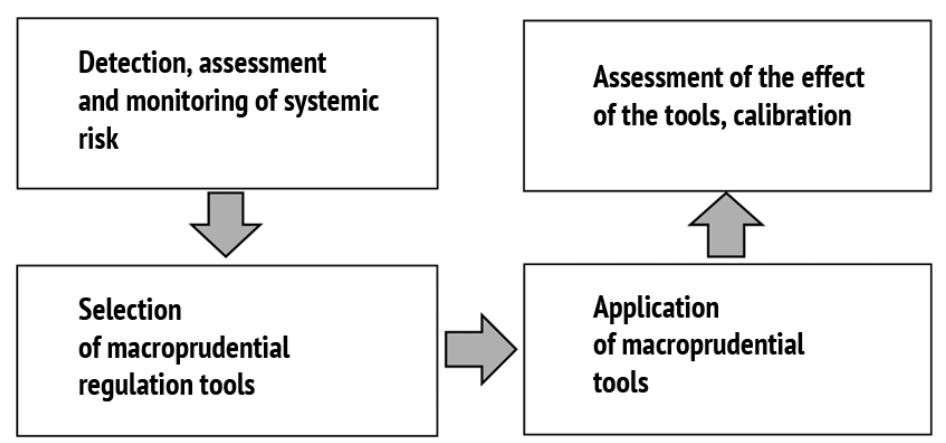

Source:Authoring based on [5]

Figure 2

Chart of weighted contribution index of Russia's Top 10 banks to the systemic liquidity risk (DD/MM/MY)

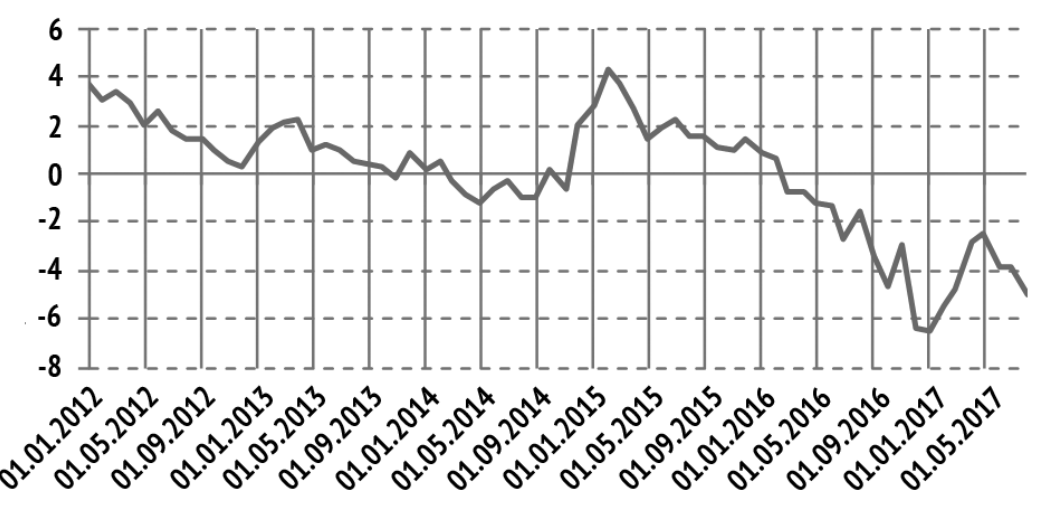

Source:Authoring

Figure 3

Changes in Industrial Production Index, its growth rates and nominal GDP (DD/MM/VY)

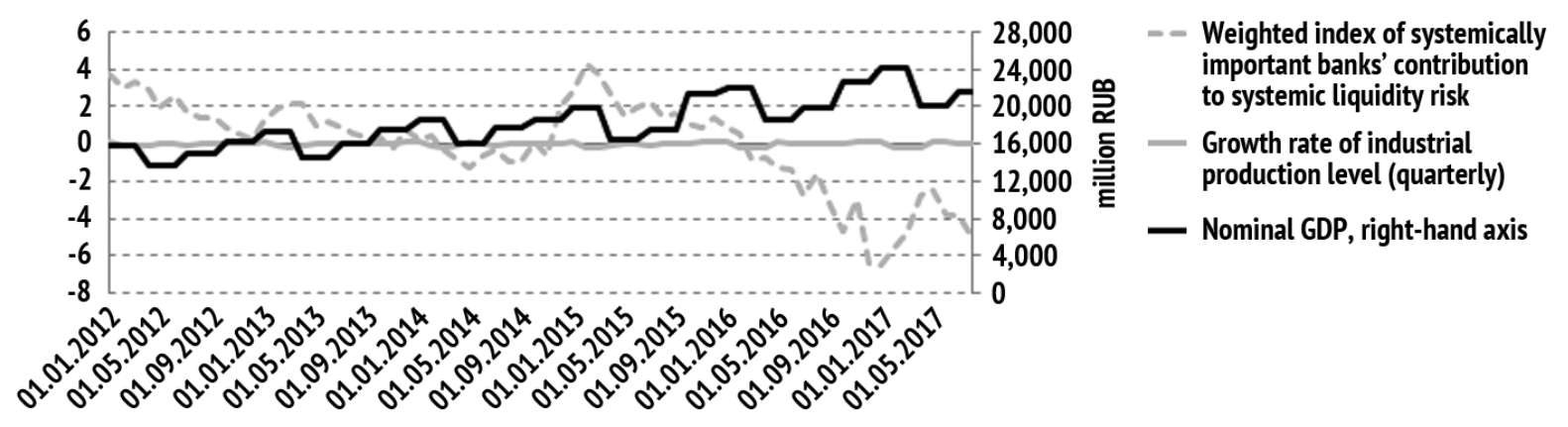

Source:Authoring

Please cite this article as: Seryakova E.V. Assessing the Russian Major Banks' Contribution to the Systemic Liquidity Risk Propagation in Banking. Digest Finance, 2018, vol. 23, iss. 4, pp. 441-452. https://doi.org/10.24891/df.23.4.441 


\section{References}

1. Karminskii A.M., Stolbov M.I., Shchepeleva M.A. Sistemnyi risk finansovogo sektora: otsenka i regulirovanie: monografiya [Systemic risk of the financial sector: assessment and regulation: a monograph]. Moscow, Nauchnaya biblioteka Publ., 2017, 284 p.

2. Kuznetsova V.V. Politika finansovoi stabil'nosti: mezhdunarodnyi opyt: monografiya [Financial stability policy: the international experience: a monograph]. Moscow, KURS Publ., INFRA-M Publ., 2014, 48 p.

3. Osiński J., Seal K., Hoogduin L. Macroprudential and Microprudential Policies: Toward Cohabitation, 2013,28 p. URL: http://www.imf.org/external/pubs/ft/sdn/2013/sdn1305.pdf

4. Unkovskaya T. [Systematic comprehension of financial stability: the paradox solving]. Ekonomicheskaya teoriya, 2009, no. 1, pp. 14-33. (In Russ.)

5. Kadomtseva S.V., Israelyan M.A. [Macro-prudential regulation and development of the system of early warning system about potential financial instability onset in Russia]. Nauchnye issledovaniya ekonomicheskogo fakul'teta. Elektronnyi zhurnal, 2015, vol. 7, iss. 4, pp. 7-27. (In Russ.) URL: https://archive.econ.msu.ru/sys/raw.php?o=3708\&p=attachment

6. Schinasi G.J. Defining Financial Stability. IMF Working Paper, 2004, No. WP/04/187. URL: http://www.imf.org/external/pubs/ft/wp/2004/wp04187.pdf

7. Crockett A. The Theory and Practice of Financial Stability. GEI Newsletter Issue. Global Economic Institutions, 1997, no. 6. URL: https://doi.org/10.1007/BF01371939

8. Ferguson R. From Speech on Meeting of the Board of Governors of the U.S. Federal Reserve System. URL: https://www.federalreserve.gov/aboutthefed/bios/board/boardmembership.htm

9. Kaurova N. [Macroprudential Regulation of Financial Markets]. Finansovyi zhurnal = Financial Journal, 2012, no. 1, pp. 5-18. URL: http://www.nifi.ru/images/FILES/Journal/Archive/2012/1/fm_2012_1.pdf (In Russ.)

10. Voronenko C. Osnovnye riski dlya rossiiskoi bankovskoi sistemy S\&P Global Ratings [Basic risks for the Russian banking system S\&P Global Ratings].

URL: http://img.en25.com/Web/StandardPoorsRatings/X-Practice\%202017\%20Voronenko.pdf? sp_mid=86003\&sp_rid=2433486\&elq=af251 f93c03e46368098c7b45cfafc45 (In Russ.)

11. Andrievskaya I. Measuring Systemic Liquidity Risk in the Russian Banking System. University of Verona, BOFIT, 2012, no. 12, 28 p. URL: https://economics.hse.ru/data/2012/03/23/1264676623/Irina_Andrievskaya_article_5Mar2012-1.pdf

12. Aivazyan S., Andrievskaya I. et al. [Identification of systematically important financial organizations: review of methodologies]. Den'gi $i$ kredit = Money and Credit, 2011, no. 8, pp. 13-18. URL: http://www.cbr.ru/Content/Document/File/26985/aivazyan_08_11.pdf (In Russ.)

13. Manaev V.N. [Measurement of systemic risk]. Risk-menedzhment v kreditnoi organizatsii, 2013, no. 3. (In Russ.)

14. Acharya V., Pedersen L., Philippon T. et al. Measuring Systemic Risk. Working Paper, 2010, pp. 1-54.

15. Hansen L.P. Challenges in Identifying and Measuring Systemic Risk. Becker Friedman Institute for Research in Economics Working Paper, 2013, no. 2012-012, 22 p. URL: https://doi.org/10.2139/ssrn.2158946

16. Acharya V., Brownlees Ch., Engle R. et al. How to Measure and Regulate Systemic Risk. NYU Stern School of Business, 2015.

URL: http://people.stern.nyu.edu/sternfin/vacharya/public_html/measuring_and_regulating_systemic_risk-1.pdf

17. Blancher N., Mitra S., Morsy H. et al. Systemic Risk Monitoring (SysMo) Toolkit - A User Guide. IMF Working Paper, 2013, no. 13/168.

Please cite this article as: Seryakova E.V. Assessing the Russian Major Banks' Contribution to the Systemic Liquidity Risk Propagation 
18. Hurd T.R. Contagion! The Spread of Systemic Risk in Financial Networks. Springer, 2015. URL: https://doi.org/10.1007/978-3-319-33930-6

\section{Conflict-of-interest notification}

I, the author of this article, bindingly and explicitly declare of the partial and total lack of actual or potential conflict of interest with any other third party whatsoever, which may arise as a result of the publication of this article. This statement relates to the study, data collection and interpretation, writing and preparation of the article, and the decision to submit the manuscript for publication. 